Lakatos Artúr Lóránd PhD

lakatos_artur_lorand@yahoo.com kutató (Kolozsvár)

\section{A „magyar narancs”}

- "The Hungarian Orange" -

DOI 10.14232/belv.2015.4.13

http://dx.doi.org/10.14232/belv.2015.4.13

Cikkre való hivatkozás / How to cite this article: Lakatos Artúr Lóránd (2015): A „magyar narancs”. Belvedere Meridionale 27. évf. 4. sz. 156-157. pp

ISSN 1419-0222 (print) ISSN 2064-5929 (online, pdf)

(Creative Commons) Nevezd meg! - Így add tovább! 4.0 (CC BY-SA 4.0)

(Creative Commons) Attribution-ShareAlike 4.0 International (CC BY-SA 4.0)

Borvendég ZsuzsannA - PAlasik Mária: Vadhajtások. A sztálini természetátalakitási tervek átültetése Magyarországon, 1948-1956.

Budapest, 2015, Napvilág Kiadó. 227 o.

Habár a kortárs természettörténet témái és forrásai legtöbbször könnyen elérhetőek, csak észre kell őket venni, egy jól dokumentált környezettörténeti munka megírása mindig komoly energia-befektetést igényel. Ilyenkor nem a források hiányával, hanem azok szétszórtságával kell megküzdenünk. Az Állambiztonságok Történeti Levéltárának két munkatársa, Palasik Mária és Borvendég Zsuzsanna is minden bizonnyal komoly munkát fektetett be azért, hogy e jelenlegi hiánypótló mű elkészüljön. A levéltári forrásokat jelző hivatkozások mellett kiterjedt szakirodalom és sajtóanyag is felhasználásra került annak érdekében, hogy sikeresen és hitelesen kerüljön dokumentálásra egy olyan komoly történelmi probléma-jelenség, melynek alapelemei közül ugyan eddig is sokat tudtunk, azonban a közbeszéd még elenyésző töredékeit sem dokumentálta annak a jelenségnek, melyet szocialista környezetalakításnak nevezünk, és melynek bizonyos hatásait mind a mai napig érzékeljük.

Még egyetemista sem voltam, mikor kezembe került az azóta már komoly hírnévre szert tett bukaresti professzor, Lucian Boia könyve a kommunizmus mítoszairól, melyben külön fejezetet szentelt a természet átalakítást szolgáló grandiózus szovjet terveknek. Ironizálta Liszenkót, és mosolyt csalt arcomra több ízben is, például a sarkkörön túli zöldség- és citrusfélék termesztésének hruscsovi tervének megemlítésével. Nem hinném, hogy sok olyan magyar ember élne, aki nem ismeri a magyar narancs motívumát, ha máshonnan nem, a Tanú címü filmből. A Magyarországnál e tekintetben szerencsétlenebbül járt Romániában pedig, ahol a környezet átalakítás nem zárult le a sztálinizmussal, hanem folytatódott Ceausescu nemzeti-kommunizmusa alatt is, mind a mai napig kísértenek a múltnak effajta maradványai. Lásd például a kiskapusi szennyezettséget, tavakba süllyesztett falvakat, melyekből csak a templomtorony emelkedik ki, Duna-Fekete tenger csatorna megépítését. A példák sorát még folytathatnánk. Ebből kifolyólag is nagy érdeklődéssel vettem kezembe e jelen kötetet.

A kötet szövegét gazdag képillusztrációk, fényképek, rajzok tagolják, egészítik ki. Szerkezetét tekintve a több, egymáshoz viszonyítva aszimmetrikus rész tematikus alfejezetekre tagozódik. Nyelvezetét tekintve tiszta, világos, lényegre törő, a történetírói és ökológiai szakzsargonban kevésbé jártas olvasók számára is élvezhető. Legtöbb esetben a szöveg a maga 
komolyságában is humoros: hiszen manapság már nehéz megállni (keserü) mosoly nélkül az olyan megfogalmazásokat, mint például „a sarki levegö áramlásának útjába gátat emelünk és kaput nyitunk a meleg óceáni légtömegek beáramlása elött”, vagy „a bányásznak van annyi tüzelöje, hogy a gyümölcsfa télen a szobában volna tartható". Az utólagos ironikus mosolyra egyetlen fejezet esetében nincs jogosultsága a mai olvasónak, különösen a „Hátrányok és meghurcoltatások" címü olvasása közben, amikor is arról láthatunk esettanulmányokat, hogyan törhettek derékba életek, karrierek csak azért, mert egyes szakemberek nem tették magukévá az ideológiai maszlaggal füszerezett áltudományt, vagy, hogy a sikertelen termesztési kísérletek milyen kolaterális áldozatokat követeltek.

A bevezető fejezet - „A diktatúra sajátosságai a Rákosi-rendszerben" - viszonylag rövid, mindössze négy oldalra rúg, s csak nagy vonalakban foglalja össze az 1948-1956 közötti magyarországi politikai rendszer pár jellemzőjét. A „tervszerütlen tervgazdálkodás” szintén nagyon vázlatosan ír az ipari fejlesztési tervekről: itt talán a tiszalöki duzzasztómü megépítésének kereteit és jellemzőit bemutató esettanulmányt lehetne kiemelni. Remekeltek a szerzők viszont a mezőgazdasággal kapcsolatos fejezetekkel: a „Prés alatt a tudomány és a Magyar Tudományos Akadémia" a mezögazdasági termelés átalakítására vonatkozó tudományos-politikai - nehéz belső vívódásokat követően mégsem teszem a kifejezést idézőjelbe - hátteret illusztrálja. A tulajdonképpeni legterjedelmesebb és legfontosabb fejezet, „Az új növények meghonosításának programja”, amely sorra veszi a különbözö tervezett, sikertelenül vagy sikeresen meghonosított növényfajták termesztési terveit és ezek eredményeit, kezdve a gabonaféléktől - beleértve az ágas búzára való áttérésnek kontra produktív kísérletét - egészen olyan egzotikus kísérletekig, mint a kenáf (magyar nevén: rostmályva) vagy rámi (magyar nevén: kínai hócsalán) meghonosítására tett erőfeszítéseket. Mindezen kutatások, véleményem szerint, a jövő gazdaság- és környezettörténeti magyarországi bibliográfiáinak fontos részévé válhatnak. Ahogy arra a szerzők is rámutatnak, egyes esetekben eredményeseknek bizonyultak a kezdeményezések, ilyen például a rizstermesztés. Sokkal több azonban a nagy áldozatot hiábavalóan felvállaló kísérletek száma, mint történt ez például a gyapot, a füge, a teacserje és a citrusfélék meghonosításának és ipari méretekben való termelésének kísérlete. Amíg ezek meghonosítása nem járt sikerrel, akadt olyan növény is, amelynek meghonosítása túl jól is sikerült: ilyen a selyemkóró, amely Somorjai Ferenc, a kor egyik tényleg kiemelkedő mezőgazdasági szakértője elutasító szakvéleménye ellenére lett politikai akaratból meghonosítva, és mára már az egyik legagresszívabban terjedő gyomnövények között van számon tartva az alföldi megyékben.

Az alaposan megírt és gazdagon illusztrált fejezetet még három kisebb, az átalakításokat a propaganda terén megjelenítő, az átalakítással kapcsolatos retorziók és a tervek utóéletéről szóló fejezetek egészítik ki.

A szerzőpárosnak az a törekvése, hogy érzékeltesse és illusztrálja a szovjet, Micsurin és Liszenko nevével fémjelzett szovjet természetátalakítási kísérletek magyarországi gyakorlatba ültetését, sikeresnek mondható. Külön értékelendő, hogy a kötet nem változott megírás közben fekete könyvvé, hanem a sok negatívum mellett a pozitívumokat is ismerteti. Gyakorlott történészi, ugyanakkor kezdő környezettörténészi minőségemben csak remélni tudom, hogy e történetírói kezdeményezésnek lesz még folytatása a közeljövőben. Hiszen a múlt megismerése okulást, példát kínál, és kevés olyan, egy időben klasszikus és aktuális probléma létezik, mint az ember viszonya környezetével. 